Eur. J. Clin. Chem. Clin. Biochem.

Vol. 32, 1994, pp. 901-904

(c) 1994 Walter de Gruyter \& Co. Berlin · New York

\title{
Magnesium Metabolism in Erythrocytes of Patients with Chronic Renal Failure and after Renal Transplantation
}

\author{
By J. Vormann ${ }^{1}$, T. Günther ${ }^{1}$, B. Perras ${ }^{2}$ and P. M. Rob ${ }^{2}$ \\ 1 Institut für Molekularbiologie und Biochemie, Freie Universität Berlin, Berlin, Germany \\ ${ }^{2}$ Klinik für Innere Medizin, Medizinische Universität zu Lübeck, Lübeck, Germany
}

(Received July 4/September 9, 1994)

Summary: Plasma and erythrocyte $\mathrm{Mg}^{2+}$ concentrations were found to be increased in 14 haemodialysis patients with chronic renal failure and in 7 chronic renal failure patients receiving chronic ambulatory peritoneal dialysis. The rate of $\mathrm{Na}^{+} / \mathrm{Mg}^{2+}$ antiport was significantly higher in haemodialysis patients, but not in chronic ambulatory peritoneal dialysis patients (control: $0.15 \pm 0.02$, haemodialysis: $0.46 \pm 0.08$, chronic ambulatory peritoneal dialysis: $0.21 \pm 0.06 ; \mathrm{Mg}^{2+}, \mathrm{mmol} / 30 \mathrm{~min} \times 1$ cells). High erythrocyte $\mathrm{Mg}^{2+}$ content in chronic renal failure results from the increased plasma $\mathrm{Mg}^{2+}$, which induces elevated $\mathrm{Mg}^{2+}$ uptake during haematopoiesis. An increased rate of $\mathrm{Na}^{+} / \mathrm{Mg}^{2+}$ antiport, which only performs $\mathrm{Mg}^{2+}$ efflux, leads to a relatively lower erythrocyte $\mathrm{Mg}^{2+}$ content in haemodialysis patients compared with chronic ambulatory peritoneal dialysis patients. The elevated $\mathrm{Na}^{+} / \mathrm{Mg}^{2+}$ antiport in erythrocytes from haemodialysis patients was almost normalised after haemodialysis.

Incubation of normal erythrocytes with heat-inactivated plasma from haemodialysis patients led to a doubling of $\mathrm{Na}^{+} / \mathrm{Mg}^{2+}$ antiport, indicating the presence of a heat-stable, dialysable plasma factor. This factor does not accumulate in chronic ambulatory peritoneal dialysis patients. After renal transplantation all changed quantities of $\mathrm{Mg}^{2+}$ metabolism returned to normal.

\section{Introduction}

In patients with chronic renal failure, the plasma $\mathrm{Mg}^{2+}$ concentration is increased due to reduced renal excretion, and the $\mathrm{Mg}^{2+}$ content of erythrocytes is higher than in healthy controls (1). In addition, inhibition of $\mathrm{Na}^{+} /$ $\mathrm{Li}^{+}$antiport (2), activation of $\mathrm{Na}^{+} / \mathrm{H}^{+}$antiport (3), and increased concentration of $\mathrm{Na}^{+}$and $\mathrm{Ca}^{2+}$ (4) were found in erythrocytes of uraemic patients. The elevated $\mathrm{Ca}^{2+}$ content is caused by reduced activity of the $\mathrm{Ca}^{2+}$-pumping ATPase, caused by a substance circulating in uraemic plasma (5). The mechanism of the increase of the erythrocyte $\mathrm{Mg}^{2+}$ content is not known. It may be caused by increased $\mathrm{Mg}^{2+}$ influx and/or decreased $\mathrm{Mg}^{2+}$ efflux. The $\mathrm{Mg}^{2+}$ uptake may increase during erythropoiesis as a consequence of the increased plasma $\mathrm{Mg}^{2+}$ concentration, since only haematopoietic precursor cells and reticulocytes but not mature erythrocytes take up $\mathrm{Mg}^{2+}$ when incubated at increased extracellular $\mathrm{Mg}^{2+}$ concentration (6). On the other hand, uraemic plasma may alter $\mathrm{Mg}^{2+}$ flux across the erythrocyte membrane. In human erythrocytes, net $\mathrm{Mg}^{2+}$ efflux has been characterised as $\mathrm{Na}^{+} / \mathrm{Mg}^{2+}$ antiport (7). Therefore, we tested $\mathrm{Na}^{+} / \mathrm{Mg}^{2+}$ antiport in erythrocytes from chronic renal failure patients and in erythrocytes after renal transplantation, and investigated the effect of uraemic plasma on the net $\mathrm{Mg}^{2+}$ efflux and influx of normal erythrocytes.

\section{Methods}

Patients

Twenty one patients with chronic renal failure (14 on haemodialysis and 7 on chronic ambulatory peritoneal dialysis treatment) were studied (tab. 1). In haemodialysis patients, an extracorporeal, pump-assisted circulation of blood $(200 \mathrm{ml} / \mathrm{min}$ during four hours three times a week) is exposed to dialysis solution (Hospal 252. 
Tab. 1 Patients and controls.

\begin{tabular}{|c|c|c|c|c|}
\hline & \multirow[t]{2}{*}{ Controls } & \multicolumn{2}{|c|}{ Chronic renal failure } & \multirow{2}{*}{$\begin{array}{l}\text { Renal } \\
\text { transplant } \\
\text { recipients }\end{array}$} \\
\hline & & $\begin{array}{l}\text { Haemo- } \\
\text { dialysis }\end{array}$ & $\begin{array}{l}\text { Chronic } \\
\text { ambulatory } \\
\text { peritoneal } \\
\text { dialysis }\end{array}$ & \\
\hline $\begin{array}{l}\text { Number } \\
\text { (n) }\end{array}$ & 11 & 14 & 7 & 10 \\
\hline \multicolumn{5}{|l|}{ Age } \\
\hline $\begin{array}{l}\text { (years) } \\
\text { (range) }\end{array}$ & $\begin{array}{l}32.0 \\
27-40\end{array}$ & $\begin{array}{l}60.1 \\
36-74\end{array}$ & $\begin{array}{l}46.8 \\
23-59\end{array}$ & $\begin{array}{l}51.5 \\
26-70\end{array}$ \\
\hline \multicolumn{5}{|l|}{$\operatorname{Sex}(n)$} \\
\hline $\begin{array}{l}\hat{\delta} \\
+\end{array}$ & $\begin{array}{l}5 \\
6\end{array}$ & $\begin{array}{l}6 \\
8\end{array}$ & $\begin{array}{l}4 \\
3\end{array}$ & $\begin{array}{l}4 \\
6\end{array}$ \\
\hline $\begin{array}{l}\text { Hypertension } \\
\text { (n) }\end{array}$ & 0 & 6 & 6 & 5 \\
\hline
\end{tabular}

Hospal Medizintechnik GmbH, Nürnberg, Germany, $\left[\mathrm{Mg}^{2+}\right]=0.5$ $\mathrm{mmol} / \mathrm{l})$. This treatment removes toxic materials and solute by diffusion and ultra filtration through a high-flux, polysulfon haemodialyser. Blood was collected at the end of haemodialysis. In chronic ambulatory peritoneal dialysis 1.5 liters of a dialysis solution (Fresenius CAPD Standard Lösung, Fresenius AG, Bad Homburg, Germany, $\left[\mathrm{Mg}^{2+}\right]=0.5 \mathrm{mmol} / \mathrm{l}$ ) are introduced four or five times every day into the peritoneal cavity. Toxic material and solute is continuously eliminated by diffusion and ultra filtration via the membrane of the peritoneum. All the patients with chronic renal failure had received haemodialysis or chronic ambulatory peritoneal dialysis treatment for more than 6 months.

For a better discrimination between the effect of renal disease and artificial, e. g. mechanical effects of haemodialysis, blood samples were taken from some patients $(n=4)$ before and after haemodialysis treatment. Furthermore, 10 former chronic renal failure patients, who had received renal transplantation more than one year previously, with subsequent good graft function (serum creatinine concentration $<200 \mu \mathrm{mol} / \mathrm{l}$ ), were included. All transplanted patients were treated with cyclosporin. As controls, blood samples from 11 healthy subjects were analysed.

\section{Plasma and erythrocyte $\mathrm{Mg}^{2+}$}

Blood was heparinized and centrifuged for $10 \mathrm{~min}$ at $1000 \mathrm{~g}$. Plasma was withdrawn and used for the measurement of $\mathrm{Mg}^{2+}$ and $\mathrm{Ca}^{2+}$ by atomic absorption spectrophotometry (AAS, Philips SP9) after appropriate dilution with $100 \mathrm{~g} / 1$ trichloroacetic acid/1.75 g/l $\mathrm{LaCl}_{3}$. Part of the erythrocytes was taken for the measurement of the intracellular $\mathrm{Mg}^{2+}$ content. For this purpose, the erythrocytes were washed twice in $150 \mathrm{mmol} / \mathrm{l} \mathrm{NaCl}$, deproteinized with 100 $\mathrm{g} / \mathrm{l}$ trichloroacetic acid/1.75 $\mathrm{g} / \mathrm{L} \mathrm{LaCl}_{3}$, centrifuged, and the $\mathrm{Mg}^{2+}$ content of the trichloroacetic acid extract measured by AAS. The $\mathrm{Mg}^{2+}$ content was related to cell volume, determined from the haematocrit.

\section{$\mathrm{Na}+/ \mathrm{Mg}^{2+}$ antiport}

Another part of the washed erythrocytes was used for measurement of $\mathrm{Mg}^{2+}$ efflux, as already described (8). Briefly, the cells were loaded with $\mathrm{Mg}^{2+}$ by incubating a cell suspension (cell volume fraction 0.1 ) for $30 \mathrm{~min}$ at $37^{\circ} \mathrm{C}$ in $\mathrm{KCl}$ medium (in mmol/l: 140 $\mathrm{KCl}, 12 \mathrm{MgCl}_{2}, 50$ sucrose, 5 glucose, 30 Hepes/Tris, pH 7.4) with the addition of $6 \mu \mathrm{mol} / \mathrm{l}$ of the cation ionophore A23187 (Boehringer Mannheim, Germany) dissolved in dimethyl sulphoxide. For removal of the ionophore, the cells were incubated four times in $\mathrm{KCl}$ medium plus $10 \mathrm{~g} / \mathrm{l}$ bovine serum albumin for $10 \mathrm{~min}$ at $37^{\circ} \mathrm{C}$. The $\mathrm{KCl}$ medium was removed by washing the cells twice with cold $\left(4^{\circ} \mathrm{C}\right)$ cholinium chloride medium (in mmol/l: 140 cholinium chloride, 5 glucose, 30 Hepes/Tris, $\mathrm{pH}$ 7.4). This loading procedure raised the intracellular $\mathrm{Mg}^{2+}$ concentration to about $20 \mathrm{mmol} / 1$ cells. $\mathrm{Mg}^{2+}$ efflux was measured by reincubating a cell suspension (cell volume fraction 0.1 ) at $37^{\circ} \mathrm{C}$ in $\mathrm{Mg}^{2+}$-free $\mathrm{NaCl}$ medium (substitution of $\mathrm{KCl}$ in $\mathrm{KCl}$ medium by $140 \mathrm{mmol} / \mathrm{l} \mathrm{NaCl}$ ) and $\mathrm{Mg}^{2+}$-free cholinium chloride medium. At the beginning of reincubation and after $30 \mathrm{~min}, 0.5 \mathrm{ml}$ aliquots of the cell suspensions were centrifuged for $1 \mathrm{~min}$ at $10000 \mathrm{~g}$. Aliquots $(100 \mu \mathrm{l})$ of the supernatants were diluted with $1 \mathrm{ml} 100 \mathrm{~g} / 1$ trichloroacetic acid/ $1.75 \mathrm{~g} / \mathrm{LaCl} \mathrm{La}_{3}$, and $\mathrm{Mg}^{2+}$ was measured by AAS. $\mathrm{Mg}^{2+}$ efflux was calculated from the increase of $\mathrm{Mg}^{2+}$ in the reincubation media and was expressed in relation to cell volume. Cell volume was determined by measuring the haematocrit. $\mathrm{Na}^{+}$-dependent $\mathrm{Mg}^{2+}$ efflux $\left(\mathrm{Na}^{+} / \mathrm{Mg}^{2+}\right.$ antiport) was determined by subtracting the $\mathrm{Mg}^{2+}$ efflux in cholinium chloride medium from the $\mathrm{Mg}^{2+}$ efflux in $\mathrm{Na}^{+}$medium. Additionally, erythrocytes from a control were incubated for $18 \mathrm{~h}$ with heat-inactivated $\left(30 \mathrm{~min}, 56^{\circ} \mathrm{C}\right)$, uraemic plasma from four haemodialysis patients or with heat-inactivated homologous plasma. Thereafter, the cells were loaded with $\mathrm{Mg}^{2+}$ and $\mathrm{Na}^{+} / \mathrm{Mg}^{2+}$ antiport was measured.

\section{$\mathrm{Mg}^{2+}$ uptake}

Erythrocytes from a control were incubated with heat-inactivated (30 min, $56^{\circ} \mathrm{C}$ ), uraemic plasma from seven haemodialysis patients, and with heat-inactivated homologous plasma (haematocrit: 0.50 ) for $1,3,5$ and $24 \mathrm{~h}$ at $37^{\circ} \mathrm{C}$. The same incubations were performed with the addition of $3 \mathrm{mmol} / 1 \mathrm{MgCl}_{2}$. At the end of incubations, cells were washed twice with $150 \mathrm{mmol} / \mathrm{l} \mathrm{NaCl}$ and the cellular $\mathrm{Mg}^{2+}$ content was determined as described above.

\section{Results}

$\mathrm{Mg}^{2+}$ concentrations in plasma and erythrocytes were significantly increased in chronic renal failure patients receiving haemodialysis and chronic ambulatory peritoneal dialysis, thus confirming published data $(1,4)$. In renal transplant recipients, the $\mathrm{Mg}^{2+}$ content in plasma and erythrocytes was within the normal range, but lower than in controls (tab. 2).

$\mathrm{Mg}^{2+}$ contents and rates of $\mathrm{Na}^{+} / \mathrm{Mg}^{2+}$ antiport in erythrocytes of controls (tab. 2) were within the same range as reported in previous studies (9). However, $\mathrm{Na}^{+} / \mathrm{Mg}^{2+}$ antiport was elevated in haemodialysis patients, the mean value being three times that of controls. In chronic ambulatory peritoneal dialysis patients, $\mathrm{Na}^{+} / \mathrm{Mg}^{2+}$ antiport was not significantly increased. With high $\mathrm{Mg}^{2+}$ loading $(20 \mathrm{mmol} / \mathrm{l}$ cells $)$, the values represent the $V_{\max }$ of $\mathrm{Na}^{+} / \mathrm{Mg}^{2+}$ antiport. The increase in $\mathrm{Na}^{+} / \mathrm{Mg}^{2+}$ antiport in haemodialysis patients was reversible; immediately after dialysis it was significantly reduced (tab. 3) but not normalised.

After renal transplantation, the erythrocyte $\mathrm{Mg}^{2+}$ concentration and the rate of $\mathrm{Na}^{+} / \mathrm{Mg}^{2+}$ antiport were not significantly different from those in healthy controls (tab. 2). $\therefore$ 
Tab. 2 Plasma and erythrocyte $\left[\mathrm{Mg}^{2+}\right]$ and erythrocyte $\mathrm{Na}^{+} /$ $\mathrm{Mg}^{2+}$ antiport activity in chronic renal failure patients and renal transplant recipients. Mean $\pm S E M$. Least significant difference to controls according to single factor analysis of variance; *, $\mathrm{p}<0.05 ;^{* * *}, \mathrm{p}<0.001$.

\begin{tabular}{lrlll}
\hline & $\mathrm{n}$ & $\begin{array}{l}{\left[\mathrm{Mg}^{2+}\right]} \\
\text { plasma } \\
(\mathrm{mmol} / \mathrm{l})\end{array}$ & $\begin{array}{l}{\left[\mathrm{Mg}^{2+}\right]} \\
\text { erythrocytes } \\
(\mathrm{mmol} / \mathrm{lcells})\end{array}$ & $\begin{array}{l}\mathrm{Na}^{+} / \mathrm{Mg}^{2+} \text { antiport } \\
\left(\mathrm{Mg}^{2+}, \mathrm{mmol} / 30 \mathrm{~min} \times 1 \mathrm{cells}\right)\end{array}$ \\
\hline Control & 11 & $0.77 \pm 0.02$ & $2.12 \pm 0.13$ & $0.15 \pm 0.02$ \\
Haemodialysis patients & 14 & $1.04 \pm 0.05^{* * *}$ & $2.54 \pm 0.10^{*}$ & $0.46 \pm 0.08^{* * *}$ \\
Chronic ambulatory peritoneal dialysis patients & 7 & $1.01 \pm 0.06^{* * *}$ & $3.18 \pm 0.24^{* * *}$ & $0.21 \pm 0.06$ \\
Renal transplant recipients & 10 & $0.71 \pm 0.04$ & $2.10 \pm 0.12$ & $0.23 \pm 0.06$ \\
\hline
\end{tabular}

Tab. 3 Plasma $\left[\mathrm{Mg}^{2+}\right]$ and erythrocyte $\left[\mathrm{Mg}^{2+}\right]$ and $\mathrm{Na}+/ \mathrm{Mg}^{2+}$ antiport activity in haemodialysis patients $(n=4)$ before and im- mediately after haemodialysis. Significant differences according to paired Student's t-test; ${ }^{*}, \mathrm{p}<0.05 ;{ }^{* *}, \mathrm{p}<0.01$.

\begin{tabular}{llll}
\hline & & Before haemodialysis & After haemodialysis \\
\hline $\mathrm{Mg}^{2+}$ plasma & $(\mathrm{mmol} / \mathrm{l})$ & $1.43 \pm 0.14$ & $0.96 \pm 0.01^{* *}$ \\
$\mathrm{Mg}^{2+}$ erythrocytes $(\mathrm{mmol} / \mathrm{h}$ cells $)$ & $3.33 \pm 0.21$ & $3.13 \pm 0.17$ \\
$\mathrm{Na}^{+} / \mathrm{Mg}^{2+}$ antiport $\left(\mathrm{Mg}^{2+}, \mathrm{mmol} / 30 \mathrm{~min} \times 1\right.$ cells $)$ & $0.65 \pm 0.15$ & $0.30 \pm 0.15^{*}$ \\
\hline
\end{tabular}

When normal erythrocytes were incubated for $18 \mathrm{~h}$ at $37^{\circ} \mathrm{C}$ with heat-inactivated, uraemic plasma from haemodialysis patients, the $\mathrm{Mg}^{2+}$ efflux via $\mathrm{Na}^{+} / \mathrm{Mg}^{2+}$ antiport was increased from $0.25 \pm 0.02$ to $0.51 \pm 0.1$; $\mathrm{Mg}^{2+}, \mathrm{mmol} / 30$ min $\times 1$ cells (mean $\pm \mathrm{SEM}, \mathrm{n}=4$, $\mathrm{p}<0.001$ ). On the other hand, incubation of normal erythrocytes for various periods up to $24 \mathrm{~h}$ with heatinactivated, uraemic plasma from haemodialysis patients at extracellular $\mathrm{Mg}^{2+}$ concentrations up to $4.5 \mathrm{mmol} / \mathrm{l}$ (uraemic plasma with addition of $3 \mathrm{mmol} / \mathrm{l} \mathrm{MgCl}_{2}$ ) did not affect the cellular $\mathrm{Mg}^{2+}$ content (data not shown). This result shows that in uraemic plasma no factor is present which induces $\mathrm{Mg}^{2+}$ uptake in erythrocytes.

\section{Discussion}

In chronic renal failure patient plasma, the $\mathrm{Mg}^{2+}$ concentration was increased and almost normalised by haemodialysis (tab. 3). The increase of erythrocyte $\mathrm{Mg}^{2+}$ is not caused by an altered activity of the $\mathrm{Na}^{+} /$ $\mathrm{Mg}^{2+}$ antiporter, as this system in human erythrocytes is irreversible, leading only to net $\mathrm{Mg}^{2+}$ efflux when the cellular $\mathrm{Mg}^{2+}$ content is increased. Hence, $\mathrm{Mg}^{2+}$ efflux occurs in both erythrocytes from uraemic patients and in $\mathrm{Mg}^{2+}$-loaded erythrocytes from controls (10).

Human erythrocytes do not take up $\mathrm{Mg}^{2+}(11,12)$. Even during incubation with uraemic plasma at increased extracellular $\mathrm{Mg}^{2+}$, erythrocytes did not accumulate $\mathrm{Mg}^{2+}$. Therefore, the increased $\mathrm{Mg}^{2+}$ concentration in uraemic erythrocytes must be induced during haematopoiesis. In agreement with this conclusion, reticulocytes take up $\mathrm{Mg}^{2+}$ when incubated at an elevated extracellular $\mathrm{Mg}^{2+}$ concentration (6).
The difference in erythrocyte $\mathrm{Mg}^{2+}$ content in haemodialysis and chronic ambulatory peritoneal dialysis may depend on the activity of $\mathrm{Na}^{+} / \mathrm{Mg}^{2+}$ antiport. In haemodialysis, the erythrocyte $\mathrm{Mg}^{2+}$ content was lower and the $\mathrm{Na}^{+} / \mathrm{Mg}^{2+}$ antiport activity was higher than in chronic ambulatory peritoneal dialysis. The $\mathrm{Na}^{+} / \mathrm{Mg}^{2+}$ antiport of normal erythrocytes was increased when they were suspended in heat-inactivated plasma from haemodialysis patients with a high $\mathrm{Na}^{+} / \mathrm{Mg}^{2+}$ antiport. As the method of determination of $\mathrm{Na}^{+} / \mathrm{Mg}^{2+}$ antiport requires plasma-free incubation of the erythrocytes for about 4 hours prior to measurement of transport rates, this effector must have a long lasting but reversible effect on the $\mathrm{Na}^{+} / \mathrm{Mg}^{2+}$ antiporter. During haemodialysis, this effector is at least partly removed, leading to reduced $\mathrm{Na}^{+} /$ $\mathrm{Mg}^{2+}$ antiport capacity (tab. 3). In vivo, however, the maximal transport capacity of $\mathrm{Mg}^{2+}$-loaded erythrocytes is not attained and, therefore, only a small (and insignificant) reduction of total intracellular $\mathrm{Mg}^{2+}$ content was observed (tab. 3). Also, $\mathrm{Na}^{+} / \mathrm{H}^{+}$antiport, which has similar properties to $\mathrm{Na}^{+} / \mathrm{Mg}^{2+}$ antiport, was increased in chronic renal failure patients (3). A dialysable, heatstable plasma constituent with a relative molecular mass of $M_{\mathrm{r}}<3000$ from chronic renal failure patients has been reported to inhibit $\mathrm{Ca}^{2+}$ transport in normal erythrocytes (5). This effector is not identified, but possible candidates are interleukin-1, interleukin- 6 and tumour necrosis factor- $\alpha$. It has been reported that undialysed patients with chronic renal failure and patients on haemodialysis expressed increased plasma levels of these cytokines (for references see 1.c. (13)). Isolated peripheral blood mononuclear cells from chronic ambulatory peritoneal dialysis patients produced less tumour necrosis factor- $\alpha$ than cells from haemodialysis patients 
(13). However, erythrocytes do not express receptors for tumour necrosis factor- $\alpha$ (14). Therefore, it is not clear whether these cytokines can directly cause the increase of $\mathrm{Na}^{+} / \mathrm{Mg}^{2+}$ antiport.

An influence of urea (which accumulates to higher concentrations in patients receiving haemodialysis than in those receiving chronic ambulatory peritoneal dialysis) on the activity of $\mathrm{Na}^{+} / \mathrm{Mg}^{2+}$ antiport can be excluded. In normal erythrocytes, urea concentrations up to 45 $\mathrm{mmol} / 1$ did not influence $\mathrm{Na}^{+} / \mathrm{Mg}^{2+}$ antiport activity (data not shown).

The elevated $\mathrm{Na}^{+} / \mathrm{Mg}^{2+}$ antiport in haemodialysis patients is also not caused by mechanic stress during haemodialysis, because erythrocytes which were taken immediately after the dialysis procedure even had reduced $\mathrm{Na}^{+} / \mathrm{Mg}^{2+}$ antiport rates compared with those taken before dialysis (tab. 3).

Increased formation of free oxygen radicals, which may occur in erythrocytes of chronic renal failure patients due to a reduction of protective enzymes (15), can also be excluded. Free oxygen radicals have been shown to decrease rather than increase $\mathrm{Na}^{+} / \mathrm{Mg}^{2+}$ antiport in human erythrocytes (16).

In chronic renal failure patients receiving chronic ambulatory peritoneal dialysis, $\mathrm{Na}^{+} / \mathrm{Mg}^{2+}$ antiport was not changed. Probably, this procedure is more effective in eliminating the activating plasma constituent.

In all chronic renal failure patients after renal transplantation, the quantities of $\mathrm{Mg}^{2+}$ metabolism were normal, in parallel with the sufficient function of the transplanted kidney as indicated by the plasma creatinine concentration. As all transplant recipients were treated with cyclosporin, one year after transplantation, this drug does not seem to have an influence on erythrocyte $\mathrm{Mg}^{2+}$ metabolism.

It remains to be established whether cells other than erythrocytes in haemodialysis patients show a high activity of $\mathrm{Na}^{+} / \mathrm{Mg}^{2+}$ antiport. A generally increased activity of $\mathrm{Na}^{+} / \mathrm{Mg}^{2+}$ antiport in other cells might lead to an intracellular $\mathrm{Mg}^{2+}$ deficit.

\section{References}

1. Hänze, S. \& Hiller, W. (1963) Serum- and Erythrozyten-Magnesium bei renaler Insuffizienz. Klinische Wochenschrift 41 , 1055-1059.

2. Boero, R., Fabbri, A., Degli-Esposti, E., Guarena, C., Forneris, G., Lucatello, A., Sturani, A., Quarello, F., Fusaroli, M. \& Piccoli, G. (1993) Sodium-lithium countertransport activity in red blood cells of patients with IgA nephropathy. Am. J. Kidney Dis. 21 (Suppl. 2), 61-65.

3. Corry, D. B., Tuck, M. L., Nicholas, S. \& Weinman, E. J. (1993) Increased $\mathrm{Na} / \mathrm{H}$ antiport activity and abundance in uremic red blood cells. Kidney Int. 44, 574-578.

4. Krzesinski, J. M., Du, F. \& Rorive, G. (1993) Intracellular cation concentration in essential hypertension and chronic renal failure. Clin. Exp. Hypertens. 15, 461-478.

5. Lindner, A., Gagne, E.-R., Zingraff, J., Jungers, P., Drüeke, T. B., Hannaert, P. \& Garay, R. (1992) A circulating inhibitor of the $\mathrm{RBC}$ membrane calcium pump in chronic renal failure. Kidney Int. 42, 1328-1335.

6. Günther, T. \& Vormann, J. (1992) $\mathrm{Mg}^{2+}$ influx in $\mathrm{Mg}^{2+}$-depleted reticulocytes. Magnesium and Trace Elem. 10, 17-20.

7. Vormann, J. \& Günther, T. (1993) Magnesium transport mechanism. In: Magnesium and the Cell (Birch, N., ed.) Academic Press, London, pp. 137-155.

8. Günther, T. \& Vormann, J. (1989) Characterisation of $\mathrm{Mg}^{2+}$ efflux from human, rat and chicken erythrocytes. FEBS Lett. 250, 633-637.

9. Vormann, J., Günther, T., Magdorf, K. \& Wahn, U. (1992) Mineral metabolism in erythrocytes from patients with cystic fibrosis. Eur. J. Clin. Chem. Clin. Biochem. 30, 193-196.

10. Dunn, M. J. (1974) Red blood cell calcium and magnesium: Effects upon sodium and potassium transport and cellular morphology. Biochim. Biophys. Acta 352, 97-116.

11. Günther, T. \& Vormann, J. (1985) Removal and reuptake of intracellular magnesium. Magn. Bull. 7, 66-69.

12. Schatzmann, H. J. (1993) Asymmetry of the magnesium sodium exchange across the human red cell membrane. Biochim. Biophys. Acta $1148,15-18$.

13. McKenna, R. M., Macdonald, C., Bernstein, K. N. \& Rush, D. N. (1994) Increased production of tumor necrosis factor alpha by haemodialysis but not peritoneal dialysis patients. Nephron 67, 190-196.

14. Beutler, B. \& Cerami, A. (1988) Tumor necrosis, cachexia, shock, and inflammation: A common mediator. Ann. Rev. Biochem. 47, 505-518.

15. Durak, I., Akyol, Ö., Basasme, E., Canbolat, O. \& Kavutcu, M. (1994) Reduced erythrocyte defence mechanisms against free radical toxicity in patients with chronic renal failure. Nephron 66, 76-80.

16. Günther, T., Vormann, J. \& Förster, R.-M. (1994) Effect of oxygen free radicals on $\mathrm{Mg}^{2+}$ efflux from erythrocytes. Eur. J. Clin. Chem. Clin. Biochem. 32, 273-277.

Priv.-Doz. Dr. Jürgen Vormann

Freie Universität Berlin

Institut für Molekularbiologie und Biochemie

Arnimallee 22

D-14195 Berlin

Germany 